\title{
GAMBARAN TINGKAT KECEMASAN ANAK USIA 6-8 TAHUN TERHADAP PENCABUTAN GIGI DI KLINIK JURUSAN KEPERAWATAN GIGI TAHUN 2016
}

\author{
Rosdiana T.Simaremare, Manta Rosma, Rizka Yulia \\ Politeknik Kesehatan Kemenkes Medan, Jurusan Keperawatan Gigi
}

\begin{abstract}
Abstrak
Gigi sulung adalah gigi yang muncul pada masa periode anak-anak, sdimulai dari anak berumur 8 bulan hingga anak berumur 12 tahun. Oleh karena itu anak perlu mendapat perhatian khusus, terutama pada awal dimulainya pertumbuhan gigi permanen menggantikan gigi susu, umumnya anak akan cenderung cemas menghadapi pengalaman pertamanya mencabut gigi susu. Penelitian ini bersifat deskriptif dengan menggunakan lembar observasi tingkat kecemasan yang dilakukan dengan cara mengamati reaksi atau respon kecemasan yang tampak pada anak, mencakup respon fisiologis, respon perilaku, respon kognitif dan respon efektif yang menunjukkan tingkat kecemasan anak terhadap pncabutan gigi yaitu tidak ada kecemasan, kecemasan ringan, kecemasan sedang dan kecemasan berat. Penelitian ini dilakukan dengan jumlah responden sebanyak 40 orang. Data yang diperoleh langsung diambil oleh peneliti, dengan hasil anak usia 6-8 tahun baik laki-laki maupun perempuan diperoleh kriteria tidak cemas sebanyak 7 anak $(17,5 \%)$, kecemasan ringan yaitu sebanyak 17 anak (42,5\%), kecemasan sedang sebanyak 13 anak (32,5\%), kecemasan berat 3 anak (7,5\%). Hal ini menunjukkan bahwa kecemasan anak terhadap pencabutan gigi dapat dikurangi ataupun diatasi dengan dukungan orang tua, membujuk anak dengan memberikan hadiah juga bisa mengurangi kecemasan anak dikarenakan keinginnannya terhadap hadiah tersebut, kemudian keahlian perawat gigi dalam berkomunikasi (komunikasi terapeutik) kepada anak, memberikan pengetahuan mengenai pertumbuhan gigi baik kepada anak maupun orang tua.
\end{abstract}

\section{Kata Kunci :}

\section{PENDAHULUAN}

Penyelenggaraan dibidang kesehatan gigi dan mulut pada hakikatnya ditunjukkan kepada seluruh masyarakat secara optimal , dengan diselenggarakannya upaya kesehatan melalui pendekatan pemeliharaan seperti, peningkatan kesehatan (promotif), pencegahan penyakit ( preventif ), upaya pengobatan ( kuratif ), dan pemulihan kesehatan ( rehabilitatif) yang diselenggarakan secara menyeluruh, terpadu dan berkesinambungan.

Kunci keberhasilan perawatan gigi pada anak dapat ditentukan oleh pengetahuan klinis dan keterampilan dokter gigi/perawat gigi, serta ditentukan oleh kesanggupan anak untuk bekerja sama selama perawatan. Hal ini menyebabkan dokter gigi/perawat gigi yang merawat pasien anak harus mampu melakukan pengelolaan perilaku agar pasien bersikap kooperatif. Sebagian anak yang datang ke praktek dokter gigi ada yang berperilaku kooperatif dan ada pula anak yang berperilaku non kooperatif serta bersikap negatif pada perawatan gigi (Masitahapsari et.al, 2009).
Walaupun sikap negatif dan rasa cemas anak terhadap pencabutan gigi yang dilakukan oleh dokter gigi/perawat gigi bukan masalah kesehatan yang serius, akan tetapi merupakan hambatan bagi para dokter gigi/perawat gigi dalam usaha peningkatan kesehatan gigi masyarakat. Oleh karena itu penanggulangan rasa cemas terhadap pencabutan gigi perlu dicarikan jalan keluarnya (Heriandi Sutadi,1992).

Kecemasan menghadapi pencabutan gigi merupakan reaksi yang dirasakan pasien baik anak maupun orang dewasa sebelum tindakan pencabutan gigi dimulai. Perasaaan ini seringkali menjadi penyebab seseorang menghindar dari perawatan gigi (Sri H Soemartono, 2003).

Kecemasan merupakan reaksi emosi sementara yang timbul pada situasi tertentu yang dirasakan sebagai suatu ancaman ( Cattell dan Scheier dalam izzaty, 2005). Kecemasan dapat pula diartikan sebagai rasa takut pada sesuatu tanpa sebab yang jelas, yang seringkali berlansung lama (Mashar Riana, 2011).

Anak-anak yang cemas cenderung menarik diri dari lingkungan sekitar dan sulit beradaptasi. Kecemasan anak dapat berupa tingkah laku kurang kooperatif terhadap perawatan gigi sehingga anak menolak untuk dilakukan 
perawatan gigi, misalnya mendorong instrumen atau peralatan perawatan gigi agar menjauh darinya, menolak membuka mulut, menangis, sampai meronta-ronta, dan membantah ( Puspa Pertiwi dkk, 2010).

Penulis juga menemukan bahwa di Klinik Jurusan Keperawatan Gigi banyak kunjungan pasien anak-anak untuk melakukan pencabutan gigi dengan tingkat kecemasan yang berbeda-beda. Pada sebagian anak melakukan pencabutan gigi adalah hal yang tidak perlu ditakutkan namun sebagian lagi beranggapan bahwa pencabutan gigi merupakan hal yang sangat menakutkan dan membuat mereka resah ketika berada diruang tunggu, bahkan anak juga memiliki berbagai alasan agar ia tidak mendapat giliran pertama, lalu mereka saling menunjuk temannya yang juga ingin melakukan pencabutan gigi. Pada beberapa kasus ditemukan anak menangis, menjerit dan tidak mau membuka mulutnya, sehingga membutuhkan waktu untuk membujuk anak agar mau melanjutkan perawatan. Situasi ini sering dihadapi oleh perawat gigi pada saat ingin melakukan pencabutan gigi pada anak-anak usia 6-8 tahun. Rasa cemas pada anak merupakan suatu pengalaman dental yang tidak menyenangkan. Ketakutan dan kecemasan mempengaruhi tingkah laku anak dan lebih jauh lagi menentukan keberhasilan perawatan gigi.

Penelitian ini dilakukan untuk melihat tingkat kecemasan anak terhadap pencabuatan gigi yang menggambarkan keadaan khawatir, gelisah, takut, tidak tentram disertai berbagai keluhan fisik. Keadaan ini dapat terjadi dalam berbagai situasi termasuk saat anak melakukan kunjungan untuk pencabutan gigi. Selain itu kecemasan dapat menimbulkan reaksi tubuh yang akan terjadi secara berulang seperti rasa kosong di perut, jantung berdebar, keringat banyak, sakit kepala, rasa mau buang air kecil dan buang air besar. Perasaan ini disertai perasaaan ingin bergerak untuk lari menghindari hal yang dicemaskan (Stuart and Sundeen, 1998).

Berdasarkan uraian latar belakang di atas, maka penulis tertarik untuk mengetahui gambaran tingkat kecemasan anak usia 6-8 tahun terhadap pencabutan gigi di Klinik Jurusan Keperawatan Gigi tahun 2016

Berdasarkan latar belakang yang telah di uraikan diatas, penulis ingin mengetahui gambaran tingkat kecemasan anak usia 6-8 tahun terhadap pencabutan gigi di Klinik Jurusan Keperawatan Gigi tahun 2016.

\section{Tujuan Penelitian}

\section{C.1 Tujuan umum}

Untuk mengetahui gambaran tingkat kecemasan anak usia 6-8 tahun terhadap pencabutan gigi di Klinik Jurusan Keperawatan Gigi tahun 2016.

\section{C.2 Tujuan khusus}

1. Untuk mengetahui gambaran tingkat kecemasan anak yang melakukan kunjungan ke klinik Jurusan Keperawatan Gigi terhadap pencabutan gigi.
2. Untuk mengetahui gambaran tingkat kecemasan anak terhadap pencabutan gigi berdasarkan usia, yaitu usia 6-8 tahun.

3. Untuk mengetahui gambaran tingkat kecemasan anak terhadap pencabutan gigi berdasarkan jenis kelamin.

\section{Manfaat Penelitian}

1. Sebagai bahan masukan dan pengetahuan kepada seluruh mahasiswa Jurusan Keperawatan Gigi tentang tingkat kecemasan anak terhadap pencabutan gigi.

2. Berguna sebagai bahan informasi untuk penelitian selanjutnya.

3. Bahan referensi di perpustakaan Poltekkes Kementrian Kesehatan Medan Jurusan Keperawatan Gigi.

\section{TINJAUAN PUSTAKA}

Cemas dalam bahasa latin "ancixus" dan dalam bahasa Jerman "angst" kemudian menjadi "anxiety" yang berarti kecemasan, merupakan suatu kata yang dipergunakan oleh Freud untuk menggambarkan suatu efek negatif dan keterangsangan. Cemas mengandung arti pengalaman psikis yang biasa dan wajar, yang pernah dialami setiap orang dalam rangka memacu individu untuk mengatasi masalah yang sedang diahadapi dengan sebaikbaiknya (Hawari, 2000).

Kecemasan (ansietas/anxiety) adalah gangguan perasaan (affectiv) yang ditandai dengan perasaan ketakutan atau kekhawatiran yang mendalam dan berkelanjutan, namun tidak mengalami gangguan dalam menilai realitas keadaan (Jadman, 2001).

Kecemasan adalah menganggap sesuatu yang sangat buruk akan terjadi, dan ini dianggap abnormal apabila terjadi dalam situasi yang menurut kebanyakan orang dapat diatasi dengan mudah. Gangguan kecemasan mencakup sekelompok gangguan dimana rasa cemas merupakan gejala utama. Gangguan kecemasan mencakup sekelompok gangguan seperti serangan panik yaitu keadaan tiba-tiba yang penuh dengan keprihatinan, individu merasa yakin bahwa sesuatu yang mengerikan akan terjadi. Perasaan ini biasanya disertai beberapa gejala fisik, misalnya jantung berdebar-debar, kehabisan nafas, berkeringat, otot-otot bergetar, dan sakit kepala (Rahmat $\mathrm{H}$ Dede, 2009).

Kecemasan merupakan reaksi emosional yang timbul oleh penyebab yang tidak spesifik yang menimbulkan perasaan tidak nyaman dan merasa terancam. Keadaan emosi ini biasanya merupakan pengalaman individu yang tidak diketahui secara khusus penyebabnya (Kaplan HI \& Sadock BJ, 1998).

Kecemasan juga dapat didefenisikan sebagai suatu unsur utama dari perasaan, dalam kehidupan dan merupakan naluri yang memperingatkan manusia akan adanya bahaya agar siap melindungi dan mempertahankan diri dari ancaman tersebut (Hendrastuti Fajriani, 2003). 


\section{A.1.1 Mengetahui Kecemasan}

Kecemasan merupakan respon emosi tanpa objek yang spesifik. Kecemasan adalah kebingungan, kekhawatiran pada sesuatu yang akan terjadi dengan penyebab yang tidak jelas dan dihubungkan dengan perasaan tidak menentu (Suliswati, 2005).

Kecemasan dapat dibedakan dengan ketakutan (fear) jika ketakutan sumbernya jelas, tetapi kecemasan tidak jelas. Jenis cemas itu dapat berupa:

a. Kecemasan yang mengambang (free floating anxiety) : yaitu kecemasan yang tidak ada hubungannya dengan suatu pemikiran.

b. Agitasi : Kecemasan yang disertai dengan kegelisahan motorik yang hebat.

c. Panik : Serangan kecemasan yang hebat dengan kegelisahan dan kebingungan.

Menurut (Dalami, 2009) kecemasan adalah respon emosional terhadap penilaian individu yang subjektif, yang dipengaruhi alam bawah sadar dan tidak diketahui secara khusus penyebabnya.

Maka dapat disimpulkan penyebab terjadinya kecemasan sukar untuk diperkiraan dengan tepat. Kejadian yang sama belum tentu dirasakan sama pula oleh setiap orang. Dengan kata lain suatu rangsangan atau kejadian dengan kualitas dan kuantitas yang sama dapat diinterprestasikan secara berbeda antara individu yang satu dengan yang lainnya. Secara sederhana kecemasan dapat disebabkan karena individu mempunyai rasa takut yang tidak realistis, karena mereka keliru dalam menilai suatu bahaya yang dihubungkan dengan situasi tertentu, atau cenderung menaksir secara berlebihan suatu peristiwa yang membahayakan. Kecemasan juga dapat di sebabkan karena penilaian diri yang salah, dimana individu merasa bahwa dirinya tidak mampu mengatasi apa yang terjadi atau apa yang dapat dilakukan untuk menolong diri sendiri.

Kecemasan adalah menganggapp sesuatu yang buruk akan terjadi. Gangguan kecemasan mencakup sekolompok gangguan dimana rasa cemas merupakan gejala utamanya. Gangguan kecemasan meliputi :

a. Gangguan Kecemasan merata

Seseorang yang mengalami kecemasan merata, setiap hari hidup dalam keadaan tegang, selalu merasa serba salah atau khawatir dan cenderung memberi reaksi yang berlebihan. Beberapa keluhan yang terlihat antara lain tidak tenang, tidur terganggu, kelelahan, sering sakit kepala dan jantung berdebar-debar.

b. Gangguan panik

Yaitu keadaan tiba-tiba yang penuh dengan keprihatinan, individu akan merasa yakin bahwa sesuatu yang mengerikan akan terjadi. Perasaan ini biasanya disertai beberapa gejala fisik seperti jantung berdebar-debar, berkeringat, sakit kepala.

c. Fobia

Fobia adalah ketakutan yang tidak rasional karena merasakan ketakutan yang berlebihan terhadap sesuatu atau situasi yang dianggap tidak berbahaya oleh kebanyakan orang. Orang yang mengalami fobia merasakan kecemasan yang hanya dapat diredakan dengan menghindari benda atau situasi yang menakutkan tersebut.

d. Gangguan obsesif dan kompulsif

Obsesi adalah pikiran yang terus menerus terhadap sesuatu hal, sedangkan kompulsi adalah desakan yang tidak tertahan untuk melakukan suatu tindakan tertentu. Seseorang dikatakan mengalami gangguan obsesif dan kompulsif apabila pikiran dan desakan untuk melakukan sesuatu memenuhi benaknya sepanjang waktu, sehingga benar-benar mengganggu kehidupannya (Rahmat H Dede, 2009).

Menurut (Stuart, 2006) respon terhadap kecemasan meliputi respon fisiologi, perilaku, kognitif dan efektif yaitu :

a. Respon Fisiologi

Gejala Somatik/fisik meliputi : kaku, gigi gemerutuk, suara tidak stabil

Gejala sensorik : muka merah atau pucat, lemas

Gejala kardiovaskular : berdebar-debar, lesu/lemas

Gejala pernafasan : nafas pendek/sesak, sering menarik nafas

b. Respon Perilaku

Respon kecemasan pada kognitif adalah perhatian terganggu, gelisah, tremor, terkejut, bicara cepat, kurang koordinasi, melarikan diri/menghindar dari masalah, menangis.

c. Respon Kognitif

Respon kecemasan kognitif adalah perhatian terganggu, pelupa, bingung, takut, kehilangan kendali.

d. Respon Efektif

Respon kecemasan efektif adalah mudah terganggu, tidak sabar, gelisah, tegang, gugup, ketakutan, waspada, khawatir.

\section{A.1.2 Faktor - faktor Yang Mempengaruhi Kecemasan}

Menurut (Stuart \& Sundeen, 1998) faktor yang menyebabkan terjadinya kecemasan antara lain :

a. Ancaman terhadap integritas biologi seperti:

1. Penyakit

Berbagai penyakit fisik terutama yang kronis dapat menyebabkan stres 
pada diri seseorang misalnya : penyakit jantung, hati, kanker, stroke dan HIV/AIDS.

2. Trauma fisik

3. Pembedahan

b. Ancaman terhadap konsep diri seperti:

Perubahan lingkungan, perubahan hubungan dan status sosial ekonomi.

Tingkat kecemasan dipengaruhi oleh beberapa faktor yang terkait meliputi hal berikut :

a. Potensi stresor

Stresor psikososial adalah setiap peristiwa atau keadaan yang menyebabkan perubahan kehidupan seseorang, sehingga orang tersebut terpaksa beradaptasi atau menyesuaikan diri untuk menghadapinya.

b. Maturasi (Kematangan)

Individu yang memiliki kematangan kepribadian akan lebih sukar mengalami gangguan akibat srtes. Sebaliknya individu yang berkepribadian tidak matang akan mudah mengalami stres.

c. Status pendidikan dan status ekonomi Status pendidikan dan status konomi yang rendah pada seseorang menyebabkan orang tersebut mengalami stres dibanding dengan mereka yang status pendidikan dan ekonomi yang tinggi.

d. Tingkat pengetahuan

Tingkat pengetahuan yang rendah pada seseorang akan menyebabkan orang tersebut mudah stres.

e. Keadaan fisik

Individu yang mengalami gangguan fisik seperti cidera, operasi, cacat badan lebih mudah mengalami stres. Disamping itu orang yang mengalami kelelahan juga akan lebih mudah stres.

f. Tipe kpribadian

Orang yang bertipe kepribadian A lebih mudah mengalami gangguan akibat adanya stres dibanding dengan kepribadian B.

Adapau ciri-ciri kepribadian A adalah tidak sabar, kompetitif, ambisius, ingin serba sempurna, serba buru-buru waktu, sangat setia (berlebihan) terhadap pekerjaan, agresif, mudah gelisah, mudah bermusuhan, mudah tersinggung. Sedangkan tipe B mempunyai ciri-ciri berlawanan dengan individu berkepribadian A.

g. Sosial budaya

Cara hidup individu di masyarakat sangat mempengaruhi terhadap timbulnya stres. Individu yang mempunyai cara hidup teratur dan mempunyai filsafat hidup yang jelas pada umumnya lebih sukar mengalami stres. h. Lingkungan atau situasi

Individu yang tinggal pada lingkungan yang dianggap asing akan lebih mudah mengalami stres.

i. Usia

Ada yang berpendapat bahwa usia muda lebih mudah mengalami stres dari pada usia tua, tetapi ada yang berpendapat sebaliknya.

j. Jenis kelamin

Umumnya wanita lebih mudah mengalami stres.

\section{A.1.3 Gejala Klinis Cemas}

Keluhan-keluhan yang sering dikemukakan oleh orang yang mengalami gangguan kecemasan antara lain sebagai berikut:

a. Khawatir, firasat buruk, takut akan pikirannya sendiri, mudah tersinggung.

b. Merasa tegang, tidak senang, gelisah, mudah tersinggung.

c. Gangguan pola tidur, bermimpi yang menegangkan.

d. Gangguan konsentrasi dan daya ingat.

e. Keluhan seperti rasa sakit pada otot dan tulang, pendengaran berdenging, berdebardebar, sesak nafas, gangguan pencernaan, sakit kepala (Hawari, 2004).

\section{A.1.4 Tingkat Kecemasan}

Peplau membagi tingkat kecemasan menjadi empat (Stuart, 2001) yaitu:

a. Kecemasan ringan

Dihubungkan dengan ketegangan yang dialami sehari-hari. Individu masih waspada, masih dapat memotivasi individu untuk belajar dan mampu memecahkan masalah secara efektif.

b. Kecemasan sedang

Individu terfokus pada pikiran yang menjadi perhatiannya, terjadi penyempitan lapangan persepsi, masih dapat melakukan sesuatu dengan arahan orang lain.

c. Kecemasan Berat

Lapangan persepsi individu sangat sempit. Pusat perhatiannya pada hal yang kecil dan detail (spesifik) serta tidak mampu berfikir tentang hal-hal lain. Perilaku dimaksudkan untuk mengurangi kecemasan dan perlu banyak perhatian atau arahan untuk dapat terfokus pada hal/area yang lain.

d. Panik

Individu kehilangan kendali, karena hilangnya kontrol maka tidak mampu melakukan apapun meski dengan perintah. Berkurangnya kemampuan berhubungan atau berkomunikasi dengan orang lain. 


\section{A.2 Masa Anak Usia 6-8 Tahun}

Pada usia ini anak sudah memasuki usia sekolah, pada periode ini pendapat orang tua bukan satu-satunya yang harus didengar dan diikuti, karena mulai mendengar pendapat guru atau teman. Pendapat tersebut kadang-kadang bertentangan dengan orang tuanya, sebab itu anak mulai membantah dan tidak mau menurut orang tua. Inilah yang dimaksut dengan masa negatifistis kedua, pada masa ini seingkali ditandai dengan tingkah laku mengamuk, menjerit, merusak, menyerang dan juga menyakiti diri sendiri (Sarlito, 1992).

\section{A.3 Aspek Pencabutan Gigi}

Pencabutan gigi yang ideal adalah pencabutan sebuah gigi atau akar gigi yang utuh tanpa menimbulkan rasa sakit, dengan trauma yang sekecil mungkin pada jaringan penyangganya sehingga luka bekas pencabutan akan sembuh secara normal dan tidak terdapat masalah pasca pencabutan di masa mendatang (Howe Geoffrey L, 1995).

Menurut (Joe, 2008) gigi sulung adalah gigi yang muncul pada masa periode anak-anak. Dimulai dari anak berumur 8 bulan hingga anak berumur 12 tahun. Namun pada kondisi tertentu pada orang dewasapun bisa ditemukan adanya gigi sulung yang menetap dan kondisi ini disebut dengan persistensi.

Pencabutan gigi sulung mempunyai beberapa aspek yaitu :

1. Aspek Psikologis

Pasien anak jelas sangat berbeda dengan pasien dewasa. Dalam hal ini tenaga medis harus mengetahui psikologis si anak saat pertama kali bertemu. Bagaimana sikap anak untuk pertama kali bertemu dengan tenaga medis, berada dalam ruangan, berinteraksi dengan bermacam benda dan alat dalam ruangan. Bisa dilihat sikap dan apresiasi anak tersebut, takut, senang, penasaran dan ingin tahu, acuh. Dan bermacam sikap lainnya.

2. Aspek Etiologis

Pencabutan gigi anak jelas harus memperhatikan penyebab utamanya, apabila kondisi gigi anak tidak dapat dipertahankan lagi ( tidak dapat dirawat). Insidensi terbesar pencabutan gigi anak jelas karena faktor karies gigi. Karies gigi pada anak merupakan kondisi yang sering sekali tidak begitu diperhatikan orang tua anak pada umumnya. Karies pada anak bisa mulai terjadi saat anak mulai tumbuh gigi.

3. Aspek Tumbuh dan Kembang Anak

Selain mengetahui kondisi psikologis anak, serta penyebab utama dalam penentuan pencabutan gigi anak, tenaga medis juga harus bisa mengetahui proses tumbuh dan kembang anak. Penting untuk diperhatikan, dengan mengetahui hal ini seorang tenaga medis bisa memperkirakan, efek-efek yang berhubungan dengan pertumbuhan dan perkembangan terhadap gigi geligi anak selanjutnya pasca pencabutan.
Pencabutan gigi sulung pada dasarnya memiliki prosedur yang berbeda dengan pencabutan gigi tetap pada orang dewasa. Dengan memperhatikan beberapa aspek, maka prosedur ini akan bisa dilakukan dengan mudah. Terdapat beberapa beda pencabutan anak-anak dengan orang dewasa yakni (1) Dosis obat suntik untuk anak-anak, (2) Alat khusus, (3) Kecepatan bekerja operator,(4) Gerakan relatif lebih ringan, (5) Dampak terhadap gigi penggantinya (Danunigrat, 2006).

Perencanaan yang tepat dalam memperhatikan pertumbuhan dan perkembangan gigi geligi sulung (gigi anak) akan mempermudah tenaga medis dalam menentukan perawatan gigi anak (tentunya tidak hanya pencabutan), serta memberikan informasi yang tepat dan sesuai untuk diberikan kepada orang tua anak dalam menjaga dan merawat gigi geliginya.

\section{A.3.1 Tingkah Laku Anak Saat Pencabutan Gigi}

Pasien anak usia 6-8 tahun kadang memilki cemas untuk berkunjung dan melakukan perawatan gigi di puskesmas, yang disebabkan kurang berani dan rasa percaya diri yang rendah. Perawat gigi yang mempunyai banyak waktu dengan pasien dapat menciptakan komunikasi yang efektif.

Tingkah laku anak yang di kenal oleh Frank dkk ada 4, yaitu :

1. Sangat negatif : menolak perawatan, meronta-ronta dan membantah, amat takut, menangis kuat-kuat, menarik atau mengisolasi diri, atau keduanya.

2. Sedikit negatif : mencoba bertahan, menyimpan rasa takut dari minimal sampai sedang, nervus atau menangis.

3. Sedikit positif : berhati-hati menerima perawatan dengan agak segan, dengan taktik bertanya atau menolak,cukup bersedia bekerja sama dengan dokter/perawat gigi.

4. Sangat positif : bersikap baik dengan operator, tidak ada tanda-tanda takut, tertarik pada prosedur, dan membuat kontak verbal yang baik.

Pada anak, perkembangan fungsi penguasaan diri, perkembangan emosi seperti perasaan cemas, maupun perkembangan motoriknya belum berkembang sepenuhnya. Sehingga pada suatu perawatan, perilaku anak masih sulit dikendalikan (Hendrastuti Fajriani, 2003).

Beberapa ahli melaporkan bahwa pada umumnya kecemasan timbul akibat pengalaman perawatan gigi semasa anak-anak (Heriandi Sutadi, 1992). Sumber utama kecemasan dalam pencabutan gigi pada anak adalah riwayat medik yang telah dialami. Bagi seorang anak, mungkin tidak ada bedanya antara seorang dokter umum dan dokter gigi/perawat gigi, karena mereka memakai baju putih yang sama. Rasa sakit pada 
kunjungan ke dokter di bayangkan oleh anak akan dialaminya saat berkunjung ke dokter gigi/perawat gigi (Soemartono Sri H, 2003).

Fase ( Sekolah dasar 6-12 tahun) adalah masa puncak emosionalitas, yaitu perkembangan emosi yang tinggi. Pada masa remaja awal, perkembangan emosinya menunjukkan sifat yang sensitif dan reaktif yang sangat kuat terhadap berbagai peristiwa atau situasi emosional. Emosinya bersifat negatif dan temperamental, mudah tersinggung, marah atau mudah sedih dan murung (Mashar Riana, 2011).

Biasanya sikap seorang anak sering berubahubah dalam waktu singkat, terkadang anak mau melakukan pencabutan gigi dengan baik tetapi disaat lain menjadi tidak patuh, perubahan sikap ini biasanya disebabkan keinginan seorang anak untuk menghindarkan diri dari rasa sakit atau rasa tidak nyaman yang ditafsirkan sebagai sesuatu yang menggangu kesenangannya (Hendrastuti Fajriani, 2003).

Pada umumnya penyebab kecemasan dalam pencabutan gigi pada anak timbul terutama pada alat yang dilihatnya, yang sepertinya akan membuatnya merasa sakit. Situasi dan keadaan lingkungan perawatan gigi sangat berpengaruh timbulnya rasa takut sebagai contoh ruang tunggu yang pengap atau panas berbeda dengan ruang tunggu yang sejuk dan nyaman. Kecemasan pasien anak terhadap perawatan gigi sering kali timbul karena anak merasa takut berada di ruang praktek dokter gigi. Ruangan praktek dokter gigi sebaiknya dibuat senyaman mungkin sehingga anak merasa seperti di rumahnya sendiri. Ruangan praktek tersebut dibedakan antara ruang tunggu dan ruang perawatan. Jika tempat praktek tidak terbatas hanya untuk pasien anak-anak, salah satu metode yang efektif diantaranya adalah dengan pembuatan ruang tunggu yang dibuat sedemikian rupa khusus untuk anak. Membuat ruang penerimaan yang nyaman dan hangat sehingga anak merasa tidak asing ketika memasukinya, atau dengan cara seperti memberikan reward atau hadiah sehingga anak dapat meredam kecemasannya. Oleh karena itu dekorasi ruangan dan komunikasi sangat memegang peranan penting dan erat kaitannya dengan kondisi psikologis mereka (http://guswiyan.blogspot.com/2009/10/mengapatakut-ke-dokter-gigi,html,15 juni 2010).

Faktor lain yang seringkali menimbulkan kecemasan pada perawatan gigi anak adalah keadaan lingkungan kamar praktek, seperti bau obat-obatan, peralatan, bunyi bur atau mesin. Dan pengalaman rasa sakit pada perawatan terdahulu sehingga anak akan takut pada perawatan gigi selanjutnya ( Hendrastuti Fajriani, 2003).

Pasien yang menunggu perawatan pada umumnya cemas, dan kecemasan dapat ditingkatkan oleh persepsi pasien tentang ruang praktek sebagai lingkungan yang mengancam, tentang perawat, bunyi dan cahaya (Prasetyo, 2005). Oleh karena itu dekorasi ruangan sangat memegang peranan penting dan erat kaitannya dengan kondisi psikologis pasien (Pertiwi et al, 2005).

Kerangka konsep penelitian adalah suatu hubungan atau kaitan antara konsep lainnya dari masalah-masalah yang di teliti. Kerangka konsep penelitian adalah suatu hubungan atau kaitan antara konsep-konsep atau variabelvariabel yang akan di amati (di ukur) melalui penelitian yang dilakukan ( Notoatmodjo, 2005)

1. Variabel bebas ( Independen) yaitu sifatnya mempengaruhi atau sebagai terpengaruh.

2. Variabel terikat ( Dependen ) yaitu sifatnya tergantung akibat atau terpengaruh.

\section{Variabel bebas Variabel terikat}

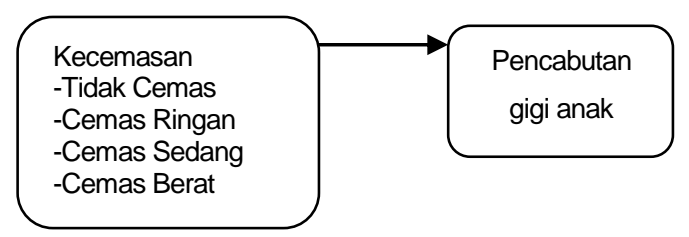

Keterangan :

Gambar 1 : hubungan variabel

1. Variabel Bebas yang mempengaruhi variabel terikat yaitu kecemasan

2. Variabel terikat adalah variabel yang dipengaruhi variabel bebas yaitu pencabutan gigi anak

\section{Definisi Operasional}

Untuk mencapai tujuan yang diinginkan dalam penelitian ini, peneliti menetukan defenisi operasional yang diteliti sebagai berikut:

1. Kecemasan merupakan reaksi yang timbul pada anak berupa kegelisahan, kekhawatiran, keresahan atau penolakan yang timbul dalam diri anak terhadap pencabutan gigi yang akan diterimanya dengan mengukur tingkat kecemasan anak berupa tidak cemas, kecemasan ringan, kecemasan sedang dan kecemasan berat.

2. Pencabutan gigi sulung adalah suatu proses dikeluarkannya gigi sulung dari soketnya dengan menggunakan tang gigi sulung setelah dilakukan anastesi.

\section{METODE}

\section{A. Jenis dan Desain Penelitian}

Jenis penelitian yang dipakai adalah penelitian deskriptif yang bertujuan menggambarkan Tingkat Kecemasan Anak Usia 6-8 Tahun Terhadap Pencabutan Gigi di Klinik Jurusan Keperawatan Gigi tahun 2016. 


\section{B. Lokasi dan Waktu Penelitian}

\section{B.1 Lokasi Penelitian}

Penelitian ini dilakukan di Klinik Jurusan Keperawatan Gigi.

\section{B.2 Waktu Penelitian}

Penelitian dilakukan pada bulan Maret sampai Juni 2016 terhadap pasien pencabutan gigi anak di Klinik Jurusan Keperawatan Gigi.

\section{Populasi dan Sampel Penelitian \\ C.1 Populasi}

Populasi adalah keseluruhan objek penelitian atau objek yang diteliti (Notoatmodjo S, 2010). Populasi dalam penelitian ini adalah anak yang akan dilakukan pencabutan gigi di Klinik Jurusan Keperawatan Gigi.

\section{C.2 Sampel}

Sampel adalah yang diteliti dan dianggap mewakili seluruh populasi (Notoatmodjo S, 2010). Menurut (Arikunto Suharsimi, 2006) apabila subjeknya kurang dari 100, lebih baik diambil semua sehingga penelitian merupakan penelitian populasi, tetapi jika jumlah subjeknya besar, dapat diambil $10-15 \%$ atau $20-25 \%$ atau lebih tergantung berdasarkan kemampuan peneliti dilihat dari waktu, tenaga, dan dana, sempit luasnya wilayah pengamatan serta besar kecilnya resiko yang ditanggung peneliti. Sampel pada penelitian ini yaitu sebanyak 40 anak. Adapun kriteria objek penelitian, sebagai berikut:

a. Anak Usia 6-8 tahun

b. Pasien pencabutan gigi Klinik Jurusan Keperawatan Gigi

\section{Jenis dan Cara Pengumpulan Data}

Jenis data yang digunakan adalah data primer, yaitu data langsung diperoleh/diambil oleh peneliti dengan menggunakan lembar observasi tingkat kecemasan. Peneliti melakukan pengumpulan data dibantu oleh satu orang rekan. Alat dan Bahan yang digunakan adalah :

1. Lembaran Observasi tingkat kecemasan

2. Alat Tulis Menulis

Adapun kegiatan yang dilakukan dalam penelitian ini adalah sebagai berikut :

a. Peneliti berada pada ruangan klinik pencabutan gigi

b. Peneliti mengamati reaksi atau respon kecemasan yang tampak pada pasien pencabutan gigi, adapun respon kecemasan sebagai berikut :

1. Respon Fisiologi

- Gejala Fisik : kaku, gigi gemerutuk, suara tidak stabil

- Gejala Sensorik : Muka merah atau pucat, lemas

- Gejala Kardiovaskular : Berdebardebar, lesu/lemas

- Gejala Pernafasan : Nafas pendek/sesak, sering menarik nafas
2. Respon Perilaku : gelisah, tremor, terkejut, bicara cepat, kurang koordinasi, melarikan diri, menghindar, menangis

3. Respon Kognitif : Perhatian terganggu, pelupa, bingung, takut, kehilangan kendali

4. Respon Efektif : Tidak sabar, gelisah, tegang, gugup, ketakutan, waspada, khawatir

c. Kemudian peneliti memberikan skor pada respon kecemasan yang tampak, yaitu:

$0=$ Tidak ada gejala kecemasan

$1=$ Satu dari gejala yang ada

2 = Separuh dari gejala yang ada

$3=$ Lebih dari $1 / 2$ gejala yang ada

$4=$ Semua gejala ada

Langkah awal penentuan derajat kecemasan dilakukan dengan cara sebagai berikut

$$
\begin{aligned}
\text { Range } & =\frac{\text { nilai skor }}{\text { Jumla } h \text { kategori kecemasan }} \\
& =\frac{16}{4}=4
\end{aligned}
$$

Sehingga skor untuk masing-masing tingkat kecemasan adalah :
a. Skor 0-4
= Tidak ada kecemasan
b. Skor 5-8
= Kecemasan ringan
c. Skor 9-12
$=$ Kecemasan sedang
d. Skor 13-16
$=$ Kecemasan berat
Data dikumpulkan dan diklasifikasikan untuk kemudian diolah.

\section{E. Pengolahan dan Analisis Data \\ E.1 Pengolahan Data}

Setelah data dikumpulkan, dilakukan analisa data secara deskriptif dan disajikandalam bentuk tabel distribusi frekuensi. Data yang diperoleh dari penelitian ini diolah dengan cara :

1. Editing

Data yang diperoleh atau dikumpulkan akan diperiksa kembali kebenarannya.

2. Coding

Data yang sudah di edit kemudian dilakukan pengkodean untuk memudahkan pengisian atau entri data di komputer.

3. Tabulating

Setelah dilakukan pengkodean kemudian data dimasukkan ke dalam tabel untuk memudahkan penganalisaan data

Untuk mengetahui kecemasan yang timbul pada anak usia 6-8 tahun terhadap pencabutan gigi di Klinik Jurusan Keperawatan Gigi, maka analisa data yang digunakan yaitu data kualiltatif dengan mengelompokkan sampel tingkat kecemasan tidak cemas, kecemasan ringan, kecemasan sedang dan kecemasan berat terhadap tindakan yang diterimanya 


\section{A. HASIL}

Sesuai dengan jadwal penelitian yang telah disusun sebelumnya, maka telah dilakukan peneletian di Klinik Jurusan Keperawatan Gigi dengan hasil penelitian sebagai berikut :

\section{A.1 Gambaran Responden}

Penelitian dilakukan pada pasien pencabutan gigi anak di Klinik Jurusan Keperawatan Gigi dengan mengambil sampel sebanyak 40 anak dengan gambaran sampel sebagai berikut :

Tabel A.1.1 Distribusi Frekuensi Responden Menurut Jenis Kelamin dan Usia

\begin{tabular}{ccccccc}
\hline No. & $\begin{array}{c}\text { Jenis } \\
\text { Kelamin }\end{array}$ & Usia & Jumlah & $\begin{array}{c}\text { Persentase } \\
(\%)\end{array}$ \\
\hline & & 6 & 7 & 8 & & \\
1. & Laki-laki & 6 & 3 & 10 & 19 & 47,5 \\
2. & Perempuan & 2 & 6 & 13 & 21 & 52,5 \\
& & Jumlah & 40 & 100 \\
\hline
\end{tabular}

Berdasarkan tabel A.1.1 diketahui bahwa jenis kelamin perempuan lebih banyak yaitu sebesar (52\%) dibandingkan jenis kelamin laki-laki sebesar $(47,5 \%)$ dan usia terbanyak yaitu usia 8 tahun

Tabel A.1.2 Distribusi Frekuensi Tingkat Kecemasan Anak

\begin{tabular}{cccc}
\hline No & $\begin{array}{c}\text { Tingkat } \\
\text { Kecemasan } \\
\text { Anak }\end{array}$ & Jumlah & $\begin{array}{c}\text { Persentase } \\
(\boldsymbol{\%})\end{array}$ \\
\hline $\mathbf{1}$ & Tidak Cemas & 7 & 17,5 \\
$\mathbf{2}$ & Ringan & 17 & 42,5 \\
$\mathbf{3}$ & Sedang & 13 & 32,5 \\
$\mathbf{4}$ & Berat & 3 & 7,5 \\
\hline & Jumlah & 40 & 100 \\
\hline
\end{tabular}

Berdasarkan tabel A.1.2 dapat dilihat dari total 40 anak yang diamati, diperoleh tingkat kecemasan anak usia 6-8 tahun dengan kriteria ringan yaitu sebanyak 17 anak (42,5\%), kecemasan sedang sebanyak 13 anak (32,5\%), kemudian dengan kategori tidak cemas sebanyak 7 anak $(17,5 \%)$ dan kecemasan berat 3 anak $(7,5 \%)$.

Tabel A.1.3 Distribusi Frekuensi Tingkat Kecemasan Anak Berdasarkan Usia

\begin{tabular}{|c|c|c|c|c|c|c|c|c|c|c|c|}
\hline \multirow{3}{*}{ No } & \multirow{3}{*}{ Usia } & \multicolumn{8}{|c|}{ Tingkat Kecemasan } & \multirow{3}{*}{ Jlh } & \multirow{3}{*}{$\begin{array}{c}\text { Persentasi } \\
(\%)\end{array}$} \\
\hline & & \multicolumn{2}{|c|}{$\begin{array}{c}\text { Tidak } \\
\text { Cemas }\end{array}$} & \multicolumn{2}{|c|}{ Ringan } & \multicolumn{2}{|c|}{ Sedang } & \multicolumn{2}{|c|}{ Berat } & & \\
\hline & & Jlh & $\%$ & Jlh & $\%$ & Jlh & $\%$ & Jlh & $\%$ & & \\
\hline 1 & $\begin{array}{c}6 \\
\text { Tahun }\end{array}$ & 1 & 2,5 & 3 & 7,5 & 4 & 10 & 0 & 0 & 8 & 20 \\
\hline 2 & $\begin{array}{c}7 \\
\text { Tahun }\end{array}$ & 1 & 2,5 & 4 & 10 & 3 & 7,5 & 1 & 2,5 & 9 & 22,5 \\
\hline 3 & $\begin{array}{c}8 \\
\text { tahun }\end{array}$ & 5 & 12,5 & 10 & 25 & 6 & 15 & 2 & 5 & 23 & 57,5 \\
\hline $\mathbf{J u}$ & Imlah & 7 & 17,5 & 17 & 42,5 & 13 & 32,5 & 3 & 7,5 & 40 & $100 \%$ \\
\hline
\end{tabular}

Berdasarkan tabel A.1.3 dapat dilihat tingkat kecemasan terbanyak pada anak usia 6 tahun yaitu berada pada kategori ringan sebesar $(7,5 \%)$ begitu juga pada anak usia 7 dan 8 tahun tingkat kecemasan terbanyak berada pada kategori ringan, anak usia 7 tahun sebesar (10\%) dan pada anak usia 8 tahun sebesar $(25 \%)$.

Tabel A.1.4 Distribusi Frekuensi Tingkat Kecemasan Anak Berdasarkan Jenis Kelamin

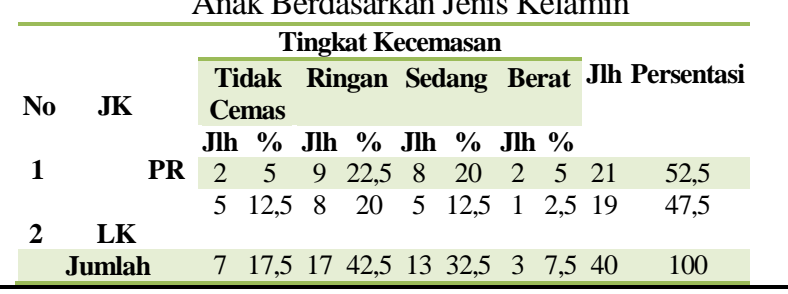

Berdasarkan tabel A.1.4 dapat dilihat tingkat kecemasan terbanyak pada jenis kelamin perempuan yaitu pada kategori ringan sebesar $(22,5 \%)$ begitu juga dengan jenis kelamin laki-laki sebesar $(20 \%)$.

\section{A.2 Pembahasan}

1. Gambaran Responden

Berdasarkan jenis kelamin (lihat tabel A.1.1) dapat dilihat jenis kelamin anak yang terbanyak adalah perempuan dan berdasarkan usia terbanyak adalah 8 tahun, usia 6-8 tahun berkaitan dengan usia awal dimulainya pertumbuhan gigi permanen menggantikan gigi susu, sehingga umumnya anak usia 6-8 tahun akan cenderung cemas menghadapi pengalaman pertamanya mencabut gigi susu. Menurut (Sarwono, 2005) usia turut mempengaruhi kematangan pribadi seseorang dalam pengambilan keputusan, umur ikut menentukan kecemasan, biasanya kecemasan sering dialami oleh usia muda. Faktor lain yang mempengaruhi psikologis untuk pasien yaitu karena pengalaman-pengalaman atau informasi tentang pencabutan gigi yang diperolehnya, ini sesuai dengan pendapat (Harmoko, 2010) pasien anak usia 6-8 tahun kadang memiliki rasa takut dan cemas untuk berkunjung melakukan perawatan gigi disebabkan kurang berani dan percaya diri.

Berdasarkan tingkat kecemasan (lihat tabel A.1.2) dapat dilihat pasien anak pada umumnya mengalami kecemasan dengan kategori ringan yaitu sebesar $42,5 \%$ (pencapaian nilai pada lembar observasi mencapai skor 5-8) yang berarti anak menunjukkan beberapa gejala kecemasan seperti gemetar, kaku, tegang, berkeringat, pucat, lemas, menghindar, gelisah dan bingung. Oleh karena itu sangat penting membuat ruang penerimaan yang nyaman dan hangat untuk membantu anak agar merasa tidak asing ketika memasukinya, atau seperti memberikan hadiah sehingga anak dapat meredam rasa cemasnya. Pada anak, perkembangan fungsi penguasaan diri, perkembangan emosi seperti perasaan cemas maupun perkembangan motoriknya belum berkembang sepenuhnya. Sehingga pada suatu perawatan, perilaku anak masih sulit dikendalikan (Hendrastuti Fajriani, 2003).

Tingkat kecemasan berdasarkan usia (lihat tabel A.1.3) dapat dilihat tingkat kecemasan terbanyak pada anak usia 6 tahun yaitu berada pada kategori ringan sebesar $7,5 \%$ begitu juga pada anak usia 7 dan 8 tahun tingkat 
kecemasan terbanyak berada pada kategori ringan, anak usia 7 tahun sebesar $10 \%$ dan pada anak usia 8 tahun sebesar $25 \%$. ini berarti perkembangan emosinya menunjukkan sifat yang sensitif dan reaktif yang sangat kuat terhadap berbagai peristiwa atau situasi emosional. Emosinya masih bersifat negatif dan temperamental atau mudah tersinggung, marah, mudah sedih, murung (Mashar Riana, 2011)

Tingkat kecemasan berdasarkan jenis kelamin (lihat tabel A.1.4) dapat dilihat usia 6,7 dan 8 tahun (Perempuan dan laki-laki) sama-sama berada pada kategori kecemasan ringan (skor respon kecemasan diatas 4 yaitu 5-8) yaitu jenis kelamin perempuan sebanyak 9 orang dan jenis kelamin laki-laki sebanyak 8 orang. Menurut (Kartono, 2002) Jenis kelamin perempuan lebih sensitif dan cepat peka dibandingkan laki-laki yang cenderung lebih aktif. Umumnya perempuan dalam merespon stimulus atau rangsangan lebih kuat dari pada laki-laki.

\section{A. Simpulan}

Berdasarkan hasil penelitian gambaran tingkat kecemasan anak usia 6-8 tahun terhadap pencabutan gigi di Klinik Jurusan Keperawatan Gigi tahun 2015 maka dapat disimpulkan :

1. Tingkat kecemasan anak usia 6-8 tahun baik laki-laki maupun perempuan diperoleh kriteria tidak cemas sebanyak 7 anak $(17,5 \%)$

2. Kecemasan ringan yaitu sebanyak 17 anak $(42,5 \%)$

3. Kecemasan sedang sebanyak 13 anak $(32,5 \%)$

4. Kecemasan berat 3 anak $(7,5 \%)$.

Jadi kecemasan anak terhadap pencabutan gigi dapat dikurangi dengan memberikan motivasi dan bimbingan oleh perawat gigi agar anak bersedia melakukan pencabutan gigi seperti memberikan reward atau hadiah sehingga anak dapat meredam kecemasannya atau menyimpan rasa cemasnya yang awalnya berat menjadi sedang atau bahkan menjadi ringan.

\section{B. Saran}

1. Disarankan kepada mahasiswa Jurusan Keperawatan Gigi agar selalu menerapkan komunikasi terapeutik terhadap pasien, termasuk dalam penanganan rasa cemas pada pasien pencabutan gigi anak.

2. Melakukan tindakan pencabutan gigi yang ideal dan memberi motivasi kepada anak sehingga anak tidak cemas dan khawatir terhadap tindakan pencabutan gigi untuk kunjungan selanjutnya.

3. Memberikan fasilitas, agar ruangan klinik tempat pencabutan gigi terlihat lebih menarik seperti menambahkan lebih banyak poster, boneka-boneka gigi pada dental unit atau memberi cat dengan warna-warna menarik pada dinding ruangan sehingga anak merasa nyaman.

\section{DAFTAR PUSTAKA}

Ali Mahfuzh, M, J. 2001. Psikologi Anak Dan Remaja Muslim. Pustaka Al-kautsar

Arikunto, S. 2006. Prosedur Penelitian. Jakarta : Rineka Cipta.

Caplin.J.P. 1997. Kamus Lengkap Psikologi. Jakarta : Rajawali Pers

Guswiyan, 2009. Tingkah Laku Anak Saat Pencabutan Gigi, Diunduh tanggal 27 Mei 2014 dari http://guswiyan.blogspot.com/2009/10/mengapatakut-ke-dokter-gigi,html,15

Harmoko, 2010. Komunikasi Anak Pada Pencabutan Gigi. Diunduh tanggal 27 Mei dari http://www.ncbi.nlm.nih.gov/pubmed/17656135.

Hidayat Aziz Halimul, 2004. Pengantar Konsep Keperawatan Dasar. Diunduh 27 Mei 2016 dari http://www.sunnyhillspediatricdentistry.com/; htt p://coolboom.net/ interior-design

Howe, Geoffrey L. 1995. Pencabutan Gigi geligi. Jakarta : ECG

Notoadmodjo, S. 2005. Metodologi Penelitian Kesehatan. Jakarta : Rineke Cipta

Mashar, R. 2011. Emosi Anak Usia Dini Dan Strategi Pengembangannya. Jakarta : Kencana

Ramaniah. 2003. Kecemasan Bagaimana Mengatasi Penyebabnya. Jakarta : Pustaka Populer Obor

Suryabrata, Sumadi. 1986. Psikologi Kepribadian. Jakarta : CV.Rajawali

Taqwin, Ali, 2011. Strategi Pengelolaan Rasa Takut Anak pada Perawatan Gigi, Diunduh tanggal $27 \mathrm{Mei}$ 2016 dari http://guswiyan.blogspot.com/2009/10/ mengapa-takut-ke-dokter-gigi.html.15juni2010. 